\title{
SISÄISTETTY BYROKRATIAMME
}

\author{
Riittävätkö opintokeskusten ja \\ järjestöaktivistien kaunopuheisuuden lahjat \\ nykypäivänä hälventämään sitä tervettä ja \\ kokemukseen nojautuvaa karsastusta, mitä \\ ihmiset kokevat kuunnellessaan sanan opintokerho? \\ Missä vika, jos opintokerho ei käy kaupaksi? \\ Puheenvuoron käyttäjä Liisa Korhonen on Kansan \\ Sivistystyön Liiton pedagoginen sihteeri.
}

Kuulutko ehkä yhteen tai useampaan ryhmään, jossa kehität itseäsi ja opit uutta? Tiedätkö, että itsenäinen pienryhmä, joka oppii ja harrastaa, voi anoa opiskelukuluihinsa valtion apua? Vajaat 17 tuhatta ryhmää hakee vuosittain valtionapua jonkin opintokeskuksen kautta ja selviää siis niin sanotusta valtionapubyrokratiasta. Byrokratia ei siis ole mahdotonta selvittää, mutta kuinka paljon se palvelee oppimista?

Jokainen pienryhmä joutuu jokaisen työjaksonsa alussa antamaan selvityksen opiskelunsa suunnittelusta. Suunnitelmalomakkeessa on parikymmentä kohtaa, jotka koskevat "'opintokerhon" nimeä ja kokoa, kytkentää johonkin järjestöön, työjakson pituutta, opiskelun aihetta, tietolähteitä, opiskelumenetelmiä, ryhmän yhteyshenkilöä opintokeskukseen päin ja ryhmän tilintarkastajaa. Samoja asioita kysytään uudelleen työjakson päättyessä uudella lomakkeella, jonka lisäksi ryhmä lähettää tiedot kuluistaan sekä osanottajaluettelonsa.

Kun tarjoan pienryhmälle valtionavun mahdollisuutta, esittelen samalla hakulomakkeet ja kerron "tavallisen opintokerhon" ja "korotetun valtionavun kerhon" minimiehdot, jotka ovat määrällisiä: 5 aikuista jäsentä, työjakso 5 viikkoa, 10 tai 12 kokoontumista, 20 tai 24 opiskelutuntia, kulukorvauksia anottavissa 375 tai $800 \mathrm{mk}$.

Valtionavun mahdollisuus ei useinkaan houkuta. Ihmiset kokevat valtionapuun liittyvät lomakkeet vastenmielisiksi. He aistivat, että samalla kun heille myönnetään oikeus saada opiskeluunsa tukea, heidän oikeuksiaan jollakin tavalla loukataan.
Lomake edustaa kasvotonta byrokratiaa. Kysymyksineen se panee sinut paikoilleen, määrää sinulle tehtävän: niin ja niin monta tuntia, niin ja niin monta kokoontumista, niin ja niin pitkän ajan kuluessa, niin ja niin paljolla rahalla. Muodolliset määräykset nousevat etualelle, oppimisen tarkoitus, etsimisen vapaus, rento kokeilu ja yhdessä harhailun ilo on siinä sormeiltu jo etukäteen.

Miksi eduskunnassa hyvää tarkoitusta varten säädetty laki alkaakin pilata tarkoitustaan?

Michel Foucault'lla on idea vallan tekniikasta, joka on kuri. Hän on korostanut sitä, että vallan tekniikkana kuri on luonteeltaan tuottavaa eikä niinkään tukahduttavaa. Kuri tuottaa faktoja, tosiasioita ilmiöistä ja ominaisuuksista. Se toteutuu varsin merkityksettömän tuntuisten, arkisten luokittelujen kautta. Se jäsentää meitä ihmisiä tietynlaisiksi, organisoi tekojamme.

Oppiville ryhmille tarjotut arkipäiväiset lomakkeet jäsentävät oppimisen maailman, ne tuottavat sellaisia faktoja kuin oppijoiden lukumäärän, oppivan ryhmän kokoontumisten lukumäärän, opiskelun aiheen, tietolähteet, opiskelun pääasialliset menetelmät, nimetyn opinto-ohjaajan. Nämä ovat kouriintuntuvia, positiivisia tuotoksia, joita opintokeskuksessa käsitellään, naputellaan atk-tiedostoiksi, kootaan tilastoiksi ja esitetään valtion viranomaisille valtionapujen hakemuksina. Ne ovat suoritteita, joiden perusteella opintokeskuksia punnitaan. Ne muovaavat myös opintokeskusten omakuvaa ja ennen 
kaikkea vievät työvoimaa, ajatuksia, aikaa. Tarvitaan ihmisiä ja tietojärjestelmiä faktojen käsittelyyn. Tarvitaan ihmisiä, jotka neuvovat lomakkeiden täyttöä. Tarvitaan myös ihmisiä, jotka rohkaisevat pienryhmiä toimimaan itsenäisesti oman oppimisensa ehdoilla, jotta lomakkeiden yhdenmukaistava vaikutus lievenisi. Sillä faktojen tuottamisen ohella nuo arkipäiväiset lomakkeet myös sulkevat ulos vaihtoehtoja ja niillä valvotaan, että pienryhmissä tapahtuu vain oikeata opiskelua. Ne myös antavat ihmisille kuvan siitä, mikä on tärkeää ja mistä tuntee oikean opintokerho-opiskelun.

Laissa on määritelty tähän saakka, että opintokeskusten kanssa harjoitettu opintotoiminta on luonteeltaan yleissivistävää ja kansalaisvalmiuksia kehittävää, suunnitelmallista opiskelua.

Vallan tekniikalla on tuotettu oikeata, suunnitelmallista opiskelua siten, että opintokeskus on pantu hyväksymään oppivan ryhmän suunnitelma. Oppivia ryhmiä on tuhansia. Käsittelyn rationalisoimiseksi on ollut luontevaa pyytää suunnitelmat lomakkeiden muodossa. Lomakkeiden avulla on voitu näyttää viranomaisille, että kyseessä on yleissivistävä ja kansalaisvalmiuksia kehittävä opiskelu eikä mikään alimittainen puuhastelu. Opintokeskusten sihteerit ovat opastaneet ihmisiä kultaiselle keskitielle, määrittämään itsensä turvallisesti hyväksyttävillä tavoilla. Näin sivistystyössä on samalla opetettu jäsentämään oppiminen sellaiseksi, että se täyttää normaalin mitat. Ihmiset ovat oppineet tarkkailemaan omaa oppimistaan lomakkeiden antaman ruudukon lävitse.

Viranomaiset ovat myös miettineet, mikä oppiminen on yleissivistävää ja kansalaisvalmiuksia kehittävää. Yleissivistävä ei heidän mukaansa ole ollut samaa kuin ammatillinen oppiminen, vaikka on myönnetty, että samaa oppia voi toinen haluta harrastuksesta, toinen ammatissa käyttääkseen. Rajaviiva on siis piirretty veteen.

On myös rajattu ulos niin sanottu pelkkä harjoittelu ja haluttu näyttöä siitä, että opinnoissa on mukana tiedollinen elementti. Tämä vaatimus on täytetty yksinkertaisimmin siten, että lomakkeeseen on merkitty ryhmän tietolähteeksi jokin kirja tai artikkeli tai alustus. Sivistysjärjestöissä on normin täyttämistä avustettu siten, että on laadittu valmiita kymmenen kokoontumisen ohjelmia. Oppiminen on näin tullut asialliseksi, itsestään selväksi ilmiöksi, jo olemassaolevan tiedon omaksumiseksi. Oppimisen laajempi ymmärrys, tiedon tuottamisen kiehtova monisyisyys, yllättävyys, hauskuus ja järkyttävyys ei oikein mahdu tähän kuvioon. Ja sen kuvion olemme ylioppineet, onhan asiallisuus, tosikkomaisuus ja vaihtoehdottomuus meillä muutoinkin normaalia. Kun meillä ryhmässä on hauskaa, joudumme selittämään itsellemme, että asiaa tässä kuitenkin on käsitelty koko ajan.

Lomake tekee hauskojakin olettamuksia täyttäjästään. Esimerkki: kun vapaa sivistystyö on tarkoitettu yli 15-vuotiaille, niin lomakkeessa on tähän päivään saakka kysytty oppivan ryhmän jäsenten syntymävuodet. Ikäänkuin ihmiset itse eivät osaisi laskea, milloin ovat täyttäneet 15 vuotta. Tosiasiassa kysymys on olennainen kurin tekniikan kannalta: alamaiset on tuotettu näkyville. Alamaiset tietäkööt, että heitä voidaan tarkkailla, mutta he eivät voi tietää, milloin heitä tarkkaillaan. Muistettakoon, että koko tämä kurin rakennelma, ilmiöiden nimeäminen ja rajaaminen, faktojen lajittelu ja tilastointi pyörii hyvin vaatimattomien raha-avustusten ympärillä.

On kiintoisaa seurata, mitä opintokeskuslain uusiminen tuo tullessaan. On luvassa, että ainakin oppivien ryhmien lomakkeet vähenisivät puoleen. Entä jos lain tarkoituspykälää muutettaisiin siten, että opintokeskusten toiminnan tarkoitukseksi tulisi tarjota mahdollisuuksia ihmisten oppimistilaisuuksille ja itsensä kehittämiselle? Antaisiko se ehkä tilaa oppiville ryhmille määrittää itsensä ja tarkoituksensa nykyistä väljemmin?

\section{LIISA KORHONEN}

